\title{
Hepatic Lymph Node
}

National Cancer Institute

\section{Source}

National Cancer Institute. Hepatic Lymph Node. NCI Thesaurus. Code C77640.

Any of the lymph nodes adjacent to the stomach and duodenum. 